\title{
THREE NEW SPINY EUPHORBIA ( EUPHORBIACEAE) SPECIES FROM WESTERN SAUDI ARABIA
}

\begin{abstract}
A. A. FAYED ${ }^{1} \&$ D. A. Al $-Z$ ZAHRANi ${ }^{2}$
Three shrubby, succulent, spiny Euphorbia (Euphorbiaceae) species from western Saudi Arabia are described and illustrated as new: Euphorbia madinahensis Fayed \& D.AlZahrani, Euphorbia saudiarabica Fayed \& D.Al-Zahrani and Euphorbia taifensis Fayed \& D.Al-Zahrani. Diagnostic characters, descriptions and taxonomic comments on each are given, and they are compared with closely related species. The geographical distribution of the three new species is shown.
\end{abstract}

Keywords. Arabian Peninsula, distribution, Euphorbia, Saudi Arabia, taxonomy.

In preparation for an account of the genus Euphorbia L. (Euphorbiaceae) in the Arabian Peninsula, three new shrubby, succulent, spiny species from western Saudi Arabia are here described.

\section{NEW SPECIES}

Euphorbia madinahensis Fayed \& D.Al-Zahrani, sp. nov. Figs 1, 2, 5.

Euphorbia aff. cactus Ehrenb.: Collenette, Ill. Guide Fl. Saudi Arabia 239 (1985); Collenette, Euphorbia J. 4: 102-122 (1987); Collenette, Wildfl. Saudi Arabia 309_ 310 (1999).

Frutex succulentus spinosus usque ad $1.5 \mathrm{~m}$ altus, in omni parte glaber; caules copiose ramosi, praesertim a basi, fasciculos densos ramorum usque ad $3 \mathrm{~m}$ vel plus latos facientes; rami flavovirentes fere erecti usque ad $35(-45) \mathrm{cm}$ in circumscriptio, manifeste constricti in segmenta pyriformia $(9-15 \mathrm{~cm}$ longa et prope basin $20-25 \mathrm{~cm}$ in circumscriptio), 3-5-anguli lateribus fere parallelis, angulis spinis gemellis in margine continuo corneo griseo $17 \mathrm{~mm}$ distantibus et circa $11 \mathrm{~mm}$ longis, interdum ad basin aculeolis parvis rudimentalibus instructis. Foliorum rudimenta simplicia sessilia cordata $5 \times 3 \mathrm{~mm}$, apice mucronato, margine integro, mox decidua. Cyathia terna aggregrata, centrale masculo (raro bisexuali) sessili primum florente, lateralibus bisexualibus in pedicellis 5-7 $\mathrm{mm}$ longis, crescentibus masculum centralem occultantibus; cymae involucraque

\footnotetext{
${ }^{1}$ Botany Department, Faculty of Science, Assiut University, Assiut, Egypt.

${ }^{2}$ Science Department, Jeddah Teacher's College, PO Box 15758, Jeddah 21454, Saudi Arabia; e-mail: dhaferalzahrani@hotmail.com. Present address: Plant Sciences, School of Biological Sciences, Faculty of Life Sciences, University of Reading, Reading RG6 6AS, UK; e-mail: d.a.alzahrani@reading.ac.uk
} 

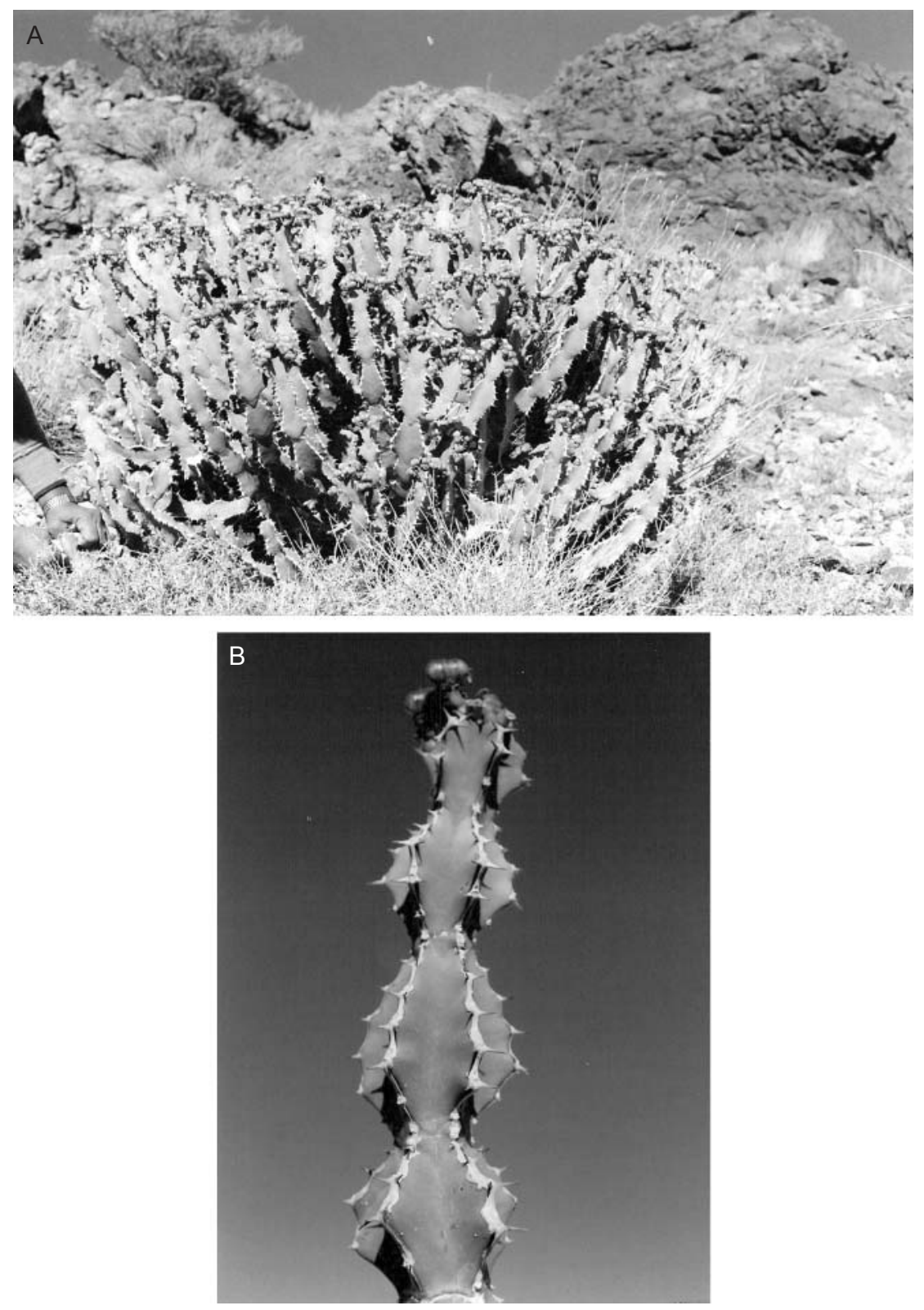

FIG. 1. Euphorbia madinahensis Fayed \& D.Al-Zahrani: mature plant (A) and close-up of branch (B) at Jabal Al-Ahmar.

bracteata, bracteis triangularibus 3-5.5 $\times 6-8 \mathrm{~mm}$ apice acuto margine fimbriato. Involucrum campanulatum, 6-7 $\mathrm{mm}$ latum $5-6 \mathrm{~mm}$ profundum; glandulae cyathiorum flavae patentes transverse elliptico-oblongae $2-2.5 \times 5-7 \mathrm{~mm}$, lobis marginalibus margine breviter fimbriatis. Flores masculi pedicello $4.2 \mathrm{~mm}$ longo, 


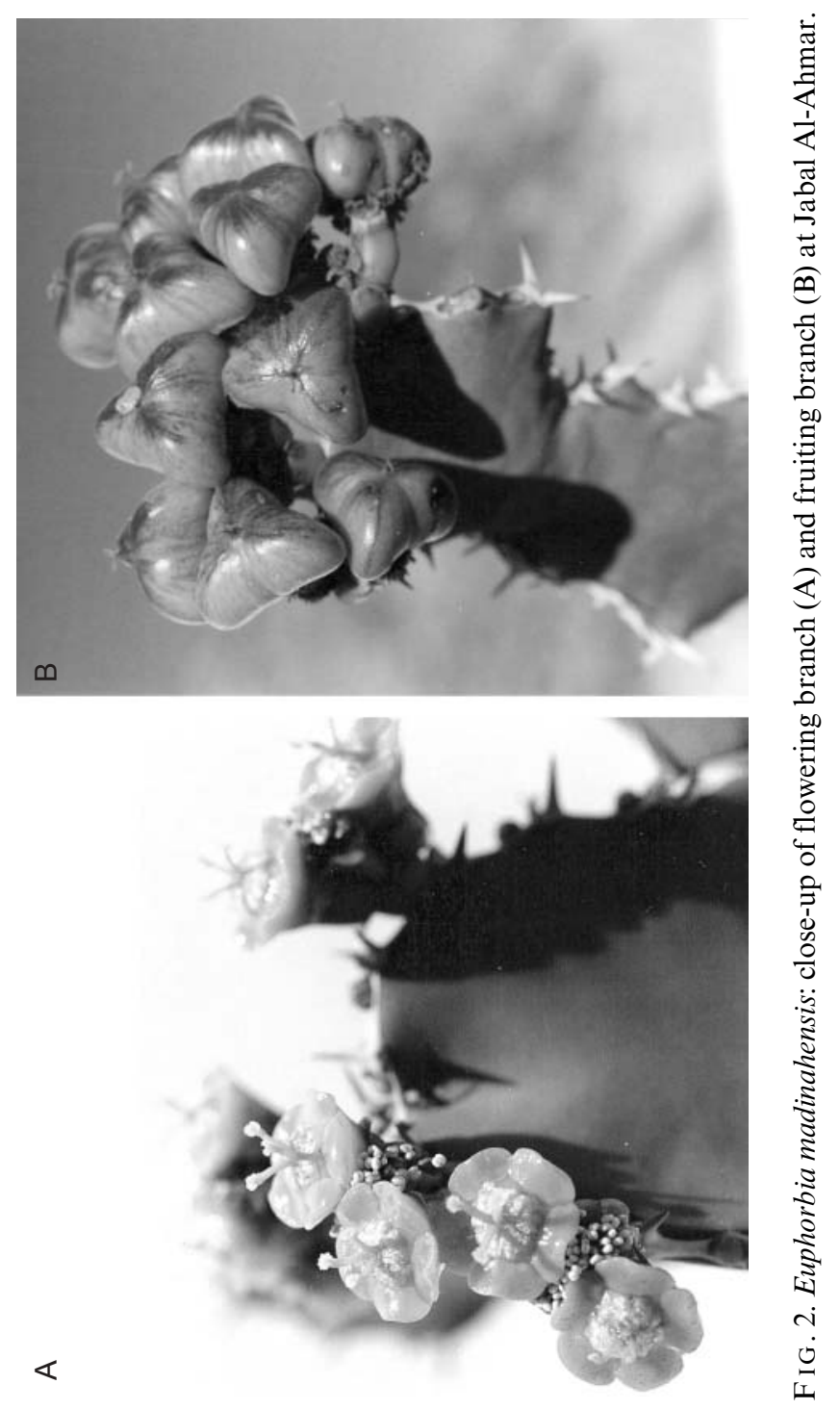


bracteolis circa $3.5 \mathrm{~mm}$ longis, in dimidio superiore dissectis. Flore feminei sessiles vel subsessiles, ramis stylorum circa $3 \mathrm{~mm}$ longis infra connatis per circa $1 \mathrm{~mm}$, ad apicem bifidis. Capsula lobis 3 rotundatus, circa $1.8 \mathrm{~cm}$ lata, matura e rubro viridis. Semina grisea subglobosa 3.5-4 mm longa laevia. - Type: Saudi Arabia: Al-Figrah highland, $95 \mathrm{~km}$ west of Madinah, 2000-2200 m alt., 16 xi 1998, D. AlZahrani 185 (holo M; iso BM, CAI, E, K, KAAU ${ }^{1}, \mathrm{KSU}$ ).

Succulent spiny shrub, up to $1.5 \mathrm{~m}$ tall, glabrous in all parts; stems branching freely, especially from the base, to form dense clumps up to $3 \mathrm{~m}$ or more in diameter; branches yellow-green, almost erect, up to $35(-45) \mathrm{cm}$ in circumference, distinctly constricted into pear-shaped segments (9-15 cm long and 20-25 cm in circumference near the base), 3-5-angled, with nearly parallel sides; angles with paired spines on continuous horny grey margins; spines $17 \mathrm{~mm}$ apart and c.11 mm long, with occasional small rudimentary prickles at the base. Leaf rudiments simple, sessile, cordate, $5 \times 3 \mathrm{~mm}$, apex mucronate, margin entire, soon deciduous. Cyathia in groups of three; the central male, rarely bisexual, sessile, flowering first; the lateral bisexual, with 5-7 mm long pedicel, obscuring the male cyathium as they develop; cymes and involucres bracteate; bracts triangular, 3-5.5 $\times 6-8 \mathrm{~mm}$, with acute apex and fimbriate margin. Involucre campanulate, 6-7 $\mathrm{mm}$ across, 5-6 $\mathrm{mm}$ deep; cyathial glands yellow, patent, transversely elliptic-oblong, 2-2.5 $\times 5-7 \mathrm{~mm}$; marginal lobes with short fimbriate margin. Pedicel of male flowers $4.2 \mathrm{~mm}$ long; bracteoles c. $3.5 \mathrm{~mm}$ long, dissected in the upper half. Female flower sessile to subsessile; style arms c. $3 \mathrm{~mm}$ long, connate for c. $1 \mathrm{~mm}$ below, bifid at apex. Capsule with 3 rounded lobes, c. $1.8 \mathrm{~cm}$ across, ripening reddish green. Seeds grey, subglobose, 3.5-4 mm long, smooth.

Distribution. Euphorbia madinahensis is named after Madinah city where the species is endemic to the nearby highlands (Fig. 5), namely Figrah, Al-Ahmar, Anagayn, Auf and Reem (1050-2350 m alt.). These highlands appear to be the northern limit for spiny euphorbias in Arabia (Collenette, 1987).

Habitat and flowering times. On granite mountains with sparse rainfall, from 1050 to $2350 \mathrm{~m}$ alt. Flowering and fruiting from September to February.

Vernacular names. Karath, Karathah.

Conservation status. According to the IUCN Red List Categories and Criteria, version 3.0 and 3.1 (IUCN, 2001, 2003), this new species should be considered Vulnerable (VU) under criteria Blab (i,ii,iii,iv,v) + 2ab (i,ii,iii,iv,v) based on observations and inferences that it has both an extent of occurrence of less than $20,000 \mathrm{~km}^{2}$ and an area of occupancy of less than $2000 \mathrm{~km}^{2}$. It is known to exist at no more than 10 locations and is in continuing decline.

\footnotetext{
${ }^{1}$ King Abdulaziz University herbarium, Jeddah, Saudi Arabia, proposed abbreviation.
} 
TABLE 1. Comparison of morphological characters in Euphorbia madinahensis and E. cactus

\begin{tabular}{|c|c|c|}
\hline Character & E. madinahensis & E. cactus \\
\hline Habit & $\begin{array}{l}\text { Up to } 1.5 \mathrm{~m} \text { tall, } 1.5-3 \mathrm{~m} \text { in } \\
\text { width }\end{array}$ & Up to $3 \mathrm{~m}$ tall, $2 \mathrm{~m}$ in width \\
\hline $\begin{array}{l}\text { Branches } \\
\text { - Colour } \\
\text { - Angles } \\
\text { - Shape } \\
\text { - Circumference } \\
\text { - Width of angle }\end{array}$ & $\begin{array}{l}\text { Yellow-green } \\
3-5 \text {, rounded, or subacute } \\
\text { Pear-shaped segments } \\
20-25 \mathrm{~cm} \\
5-8 \mathrm{~cm}\end{array}$ & $\begin{array}{l}\text { Dark green } \\
3 \text { rarely } 4 \text {, acute } \\
\text { Wing-like, compressed angles } \\
25-35 \mathrm{~cm} \\
15-20 \mathrm{~cm}\end{array}$ \\
\hline Spine size & 2-11 mm long, $17 \mathrm{~mm}$ apart & $10-25 \mathrm{~mm}$ long, $40 \mathrm{~mm}$ apart \\
\hline Bracts & $3-5.5 \times 6-8 \mathrm{~mm}$ & $2.5-3.5 \times 5 \mathrm{~mm}$ \\
\hline $\begin{array}{l}\text { Capsule } \\
\text { - Size } \\
\text { - Shape } \\
\text { - Pedicel }\end{array}$ & $\begin{array}{l}10 \times 18 \mathrm{~mm} \\
\text { Triangular, rounded } \\
2 \mathrm{~mm}\end{array}$ & $\begin{array}{l}8-9 \times 15-16 \mathrm{~mm} \\
\text { Triangular, acute } \\
2-5 \mathrm{~mm}\end{array}$ \\
\hline
\end{tabular}

Euphorbia madinahensis is closely related to Euphorbia cactus Ehrenb. It has correspondingly very stout, fleshy, yellow-green stems, with subacute angles and distinct pear-shaped segments. They are not mottled with radiating yellow streaks (a characteristic of Euphorbia cactus Ehrenb.). In addition, the branch margins of the new species are almost without undulations, while the spines are white and stout, being linked by a contiguous, grey band. The cymes cover the entire apical segments, so that the plants appear to carry balls of flowers. Moreover, the cyathia are subsessile and are subtended by triangular, obviously larger bracts. A morphological comparison between Euphorbia madinahensis and E. cactus is given in Table 1. Collenette $(1985,1987,1999)$ was aware of most of the abovementioned differences and named the plants of these populations Euphorbia sp. aff. cactus Ehrenb.

Specimens examined. SAudi Arabia. Figrah highland, $95 \mathrm{~km}$ W of Al-Madinah, 2000-2200 m alt., D. Al-Zahrani 176 (BM, E, K, KAAU, M); idem, 1 xi 1998, D. Al-Zahrani 184 (KAAU, KSU, RIY); Jibal Reem, c. 20 km N of Al-Musayjid, Madinah-Badr Hunain road, $1560 \mathrm{~m}$ alt., 7 viii 1998, D. Al-Zahrani 174 (BM, E, KAAU, KSU, M, RIY); Jibal Anagayn, c. 15 km NW of Al-Musayjid, Madinah-Badr Hunain road, 1900 m alt., 9 viii 1998, D. Al-Zahrani 177 (K, KSU); Jabal Auf, $80 \mathrm{~km} \mathrm{SSW}$ of Madinah, $1170 \mathrm{~m}$ alt., 26 xi 1986, Collenette 5945 (K, RIY); Jabal Al-Ahmar, c.100 km SW of Madinah, on a barren rocky hillside, $2300 \mathrm{~m}$ alt., 24 ii 1998, D. Al-Zahrani 152 (BM, CAI, E, K, KAAU, KSU, M, RIY).

\section{Euphorbia saudiarabica Fayed \& D.Al-Zahrani, sp. nov. Figs 3, 5.}

Frutex vel arbor parva candelabriformis succulenta spinosa, non magis quam $3 \mathrm{~m}$ alta, in omni parte glabra, caule principali unico (45-60 $\mathrm{cm}$ in circumscriptio); rami flavovirentes vel flavi, longi crassi graciles simplices 3-5-anguli 15-19 cm in circumscriptio, inferiores declinantes, terram verrentes, dein assurgentes, 


\section{A}
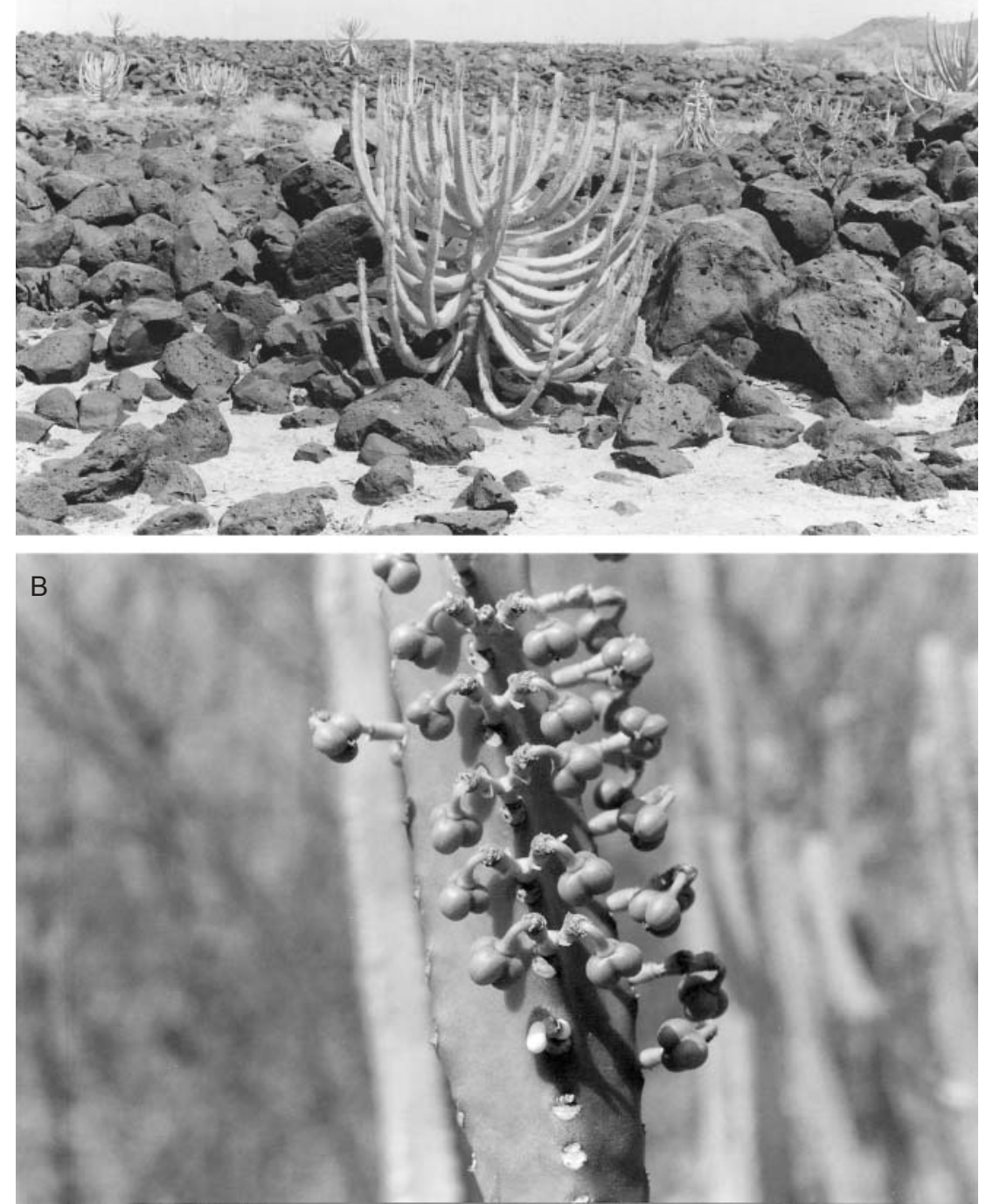

FIG. 3. Euphorbia saudiarabica Fayed \& D.Al-Zahrani: mature plant (A) and close-up of fruiting branch (B) at Thahban (between Al-Birk and Al-Qahmah).

superiores fere erecti, lateribus fere parallelis, spinis gemellis in scutis parvis non contiguis, apice nigro, $1 \mathrm{~cm}$ longis, interdum ad basin aculeolis parvis rudimentalibus instructis. Foliorum rudimenta sessilia simplicia ovata, interdum lamina oblique truncata, apice acuto, margine integro, mox decidua. Cyathia terna aggregrata, centrale masculo (raro bisexuali) sessili primum florente, lateralibus bisexualibus in pedicellis 2-4 mm longis, crescentibus masculum 
centralem occultantibus; cymae involucraque bracteata, bracteis $1.5-2 \times 1-$ $1.5 \mathrm{~mm}$, apice rotundato, margine fimbriato. Involucrum campanulatum, $4.5 \mathrm{~mm}$ latum $3.5 \mathrm{~mm}$ profundum; glandulae cyathiorum flavae transverse oblongae $2.5-$ $3.5 \times 1-1.5 \mathrm{~mm}$, lobis marginalibus margine breviter fimbriatis. Flores masculi pedicello $3.5 \mathrm{~mm}$ longo, bracteolis $3 \mathrm{~mm}$ longis, supra dissectis. Flore feminei pedicellati, pedicello $2-4 \mathrm{~mm}$ longo, ovario in stipite notabiliter reflexo, ramis stylorum $2 \mathrm{~mm}$ longis, infra connatis per $1 \mathrm{~mm}$, ad apicem bifidis. Capsula lobis 3 rotundatus, $4 \times 6-6.5 \mathrm{~mm}$, in stipite $14 \mathrm{~mm}$ longo notabiliter reflexo. Semina subglobosa 2.5-3 × 2-2.3 mm grisea laevia. - Type: Saudi Arabia: Between AlBirk and Al-Qahmah, $55 \mathrm{~km}$ N of Shoqaiq-Muhayil junction, Al-QunfudhahJizan road, 10 m alt., 5 vi 1998, D. Al-Zahrani 164 (holo M; iso BM, E, K, M).

A candelabra-like succulent spiny shrub or small tree, not exceeding $3 \mathrm{~m}$ tall, glabrous in all parts, with a single main stem (45-60 cm in circumference); branches yellow-green to yellow, long, stout, slender, simple, 3-5-angled, 15-19 cm in circumference, the lower branches arching down to sweep the ground then turning upwards, the upper ones almost erect; branch (sides) nearly parallel, with paired spines on small, non-contiguous spine shields; spines black-tipped, $1 \mathrm{~cm}$ long, with occasional small rudimentary prickles at the base. Leaf rudiments sessile, simple, ovate, sometimes with obliquely truncate lamina, apex acute, margin entire, soon deciduous. Cyathia in groups of three; the central male, rarely bisexual, sessile, flowering first; the lateral bisexual, with 2-4 mm long pedicel, obscuring the male cyathium as they develop; cymes and involucres bracteate; bracts $1.5-2 \times 1-1.5 \mathrm{~mm}$, with rounded apex and fimbriate margin. Involucre campanulate, $4.5 \mathrm{~mm}$ across, $3.5 \mathrm{~mm}$ deep; cyathial glands yellow, transversely oblong, 2.5-3.5 × 1-1.5 mm; marginal lobes with short fimbriate margin. Pedicel of male flowers $3.5 \mathrm{~mm}$ long; bracteoles $3 \mathrm{~mm}$ long, dissected above. Pedicel of female flowers 10-14 mm long; ovary on remarkably reflexed stalk; style arms $2 \mathrm{~mm}$ long, connate for $1 \mathrm{~mm}$ below, bifid at apex. Capsule with 3 rounded lobes, $4 \times 6-6.5 \mathrm{~mm}$, on $14 \mathrm{~mm}$ long, remarkably reflexed stalks. Seeds subglobose, $2.5-3 \times 2-2.3 \mathrm{~mm}$, grey, smooth.

Distribution. Endemic to the southwestern corner of Saudi Arabia along the Qunfudhah-Jizan road (Fig. 5).

Habitat and flowering times. In full sun at sea level and low-lying sites (0-30 m alt.) in fine drifting clay sand among black basalt blocks. Flowering from March to July.

Vernacular names. Saab, Suoiab.

Conservation status. Euphorbia saudiarabica has both an extent of occurrence estimated to be less than $5000 \mathrm{~km}^{2}$ and an area of occupancy estimated to be less than $500 \mathrm{~km}^{2}$. Moreover, the population size is estimated to number fewer than 250 mature individuals and it is known to exist at no more than three locations. The population at one location has been severely damaged by roadworks, which have reduced it by half. Other populations contain fewer than 30 plants, including 
juveniles. For these reasons, it should be considered that Euphorbia saudiarabica is an Endangered (EN) species based on the IUCN Red List Categories and Criteria, version 3.0 and 3.1 (IUCN, 2001, 2003) under criteria B1ab (i,ii,iii,iv,v), B2ab (i,ii,iii,iv,v), c (i,ii,iii,iv) and D. This is a precautionary preliminary assessment and further research is needed to clarify the habitat requirements and population size of the species. It is likely to become more threatened in the future, and additional ecological and biological studies should be undertaken towards effective conservation.

This new species is closely related to Euphorbia parciramulosa Schweinf. However, Euphorbia saudiarabica is readily separated by its branch margins which are almost without undulations, while the small spine shields are non-contiguous. The spines of the new species are small, white, black-tipped and resemble buffalo horns when young. Moreover, the capsules are borne on long $(14 \mathrm{~mm})$ and remarkably reflexed stalks (much more strongly reflexed than in Euphorbia parciramulosa). The capsules are smooth and relatively large $(4-5 \times 6-6.5 \mathrm{~mm})$. The glands are oblong and close to each other. A morphological comparison between Euphorbia saudiarabica and E. parciramulosa is given in Table 2 .

Specimens examined. SAudi ArABIA. Thahban, between Al-Birk and Al-Qahmah, $65 \mathrm{~km} \mathrm{~N}$ of Shoqaiq-Muhayil junction, Al Qunfudhah-Jizan road, $4 \mathrm{~m}$ alt., 5 vi 1998, D. Al-Zahrani 163 (KAAU); Near Thahaban, between Qahmah and Al-Birk, Qunfudhah-Jizan road, $3 \mathrm{~m}$ alt., 9 v 1985, Collenette 4724 (E, K, RIY); Between Al-Birk and Al-Qahmah, Al-Qunfudhah-Jizan road, 10 m alt., 7 viii 1997, D. Al-Zahrani 126 (E, KAAU); idem, 5 vi 1998, D. Al-Zahrani 164 (BM, E, K, M); 25 m alt., 10 xi 1998, D. Al-Zahrani 181 (KAAU); Between Baysh and sabia-Jizan road, $35 \mathrm{~m}$ alt., 7 v 1985, Collenette 5195 (E, RIY); Coastal area on to Yemen border from Abu-Arish, 8 iv 1983, Chaudhary 8106 (RIY).

TABLE 2. Comparison of morphological characters in Euphorbia saudiarabica and E. parciramulosa

\begin{tabular}{|c|c|c|}
\hline Character & E. saudiarabica & E. parciramulosa \\
\hline Habitat & $\begin{array}{l}\text { At sea level and low-lying sites } \\
\text { at } 0-30 \mathrm{~m} \text { alt. }\end{array}$ & On the high mountains at $2000 \mathrm{~m}$ alt. \\
\hline Habit & $\begin{array}{l}\text { Usually shrub to small tree, up } \\
\text { to } 3 \mathrm{~m} \text { tall }\end{array}$ & Tree up to $6 \mathrm{~m}$ tall \\
\hline $\begin{array}{l}\text { Branches } \\
\text { - Colour } \\
\text { - Angles } \\
\text { - Margins }\end{array}$ & $\begin{array}{l}\text { Yellow-green to yellow } \\
3-5 \\
\text { Without undulation }\end{array}$ & $\begin{array}{l}\text { Dark green } \\
3-4 \\
\text { Undulated (with wavy edges) }\end{array}$ \\
\hline Spine shields & Non-contiguous & Contiguous \\
\hline Glands & Oblong, close together & Ovate to oblong-ovate, spaced \\
\hline $\begin{array}{l}\text { Capsule } \\
\text { - Size } \\
\text { - Pedicel } \\
\text { - Surface }\end{array}$ & $\begin{array}{l}4 \times 6-6.5 \mathrm{~mm} \\
10-14 \mathrm{~mm} \text {, totally reflexed } \\
\text { Grey, smooth }\end{array}$ & $\begin{array}{l}3-4 \times 5 \mathrm{~mm} \\
2-4 \mathrm{~mm} \text {, erect to slightly reflexed } \\
\text { Mottled }\end{array}$ \\
\hline
\end{tabular}


Euphorbia taifensis Fayed \& D.Al-Zahrani, sp. nov. Figs 4, 5.

Euphorbia aff. ammak Schweinf.: Collenette, Ill. Guide Fl. Saudi Arabia 237 (1985); Collenette, Euphorbia J. 4: 102-122 (1987); Collenette, Wildfl. Saudi Arabia 307 (1999).

Arbor ramosissima succulenta spinosa usque ad $10 \mathrm{~m}$ alta, in omni parte glabra, caule principali $65-90 \mathrm{~cm}$ in circumscriptio; rami vivide virentes

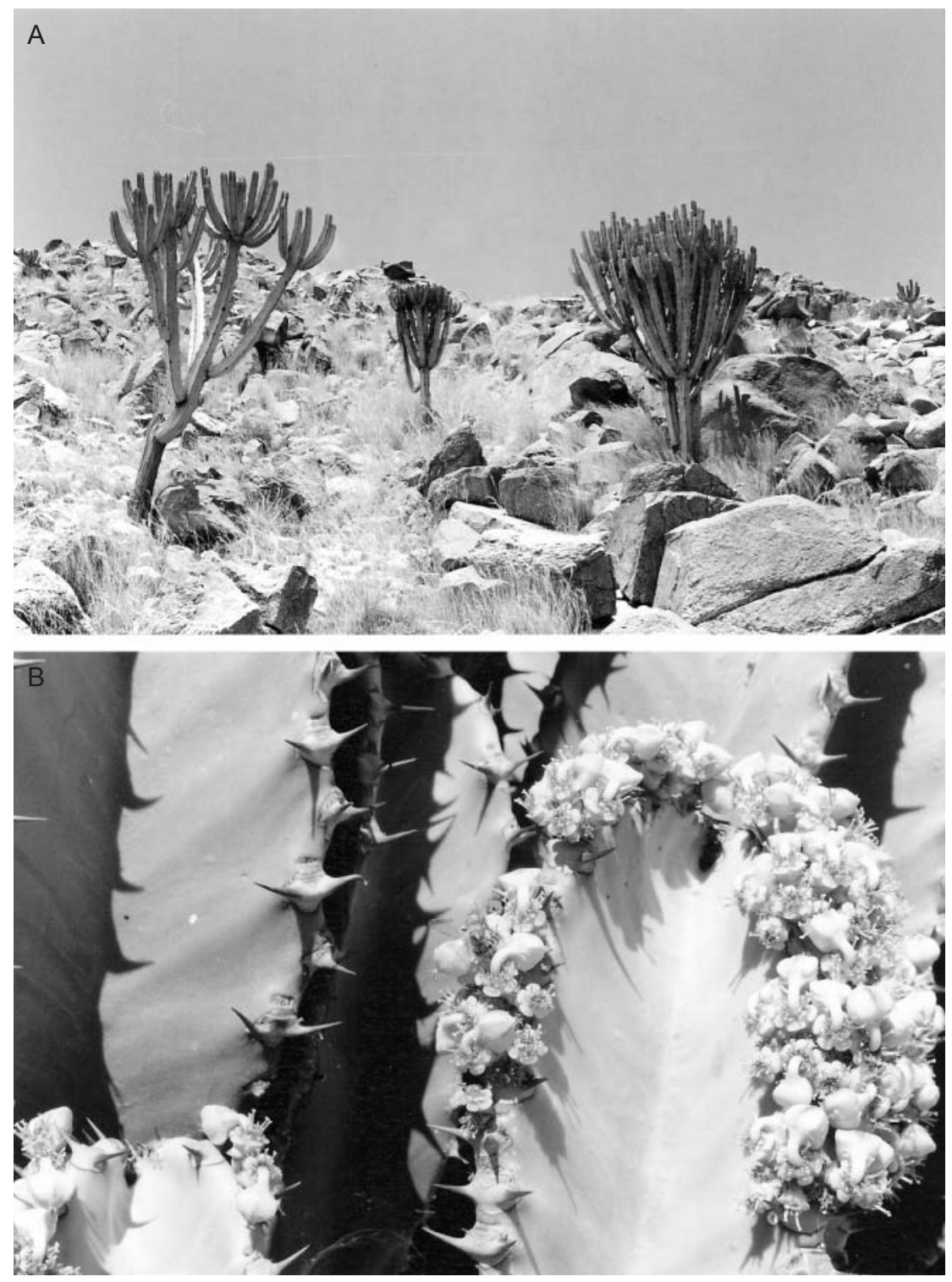

F IG. 4. Euphorbia taifensis Fayed \& D.Al-Zahrani: mature plant (A) and close-up of branches (B) at Bani Salim District, near Taif city. 

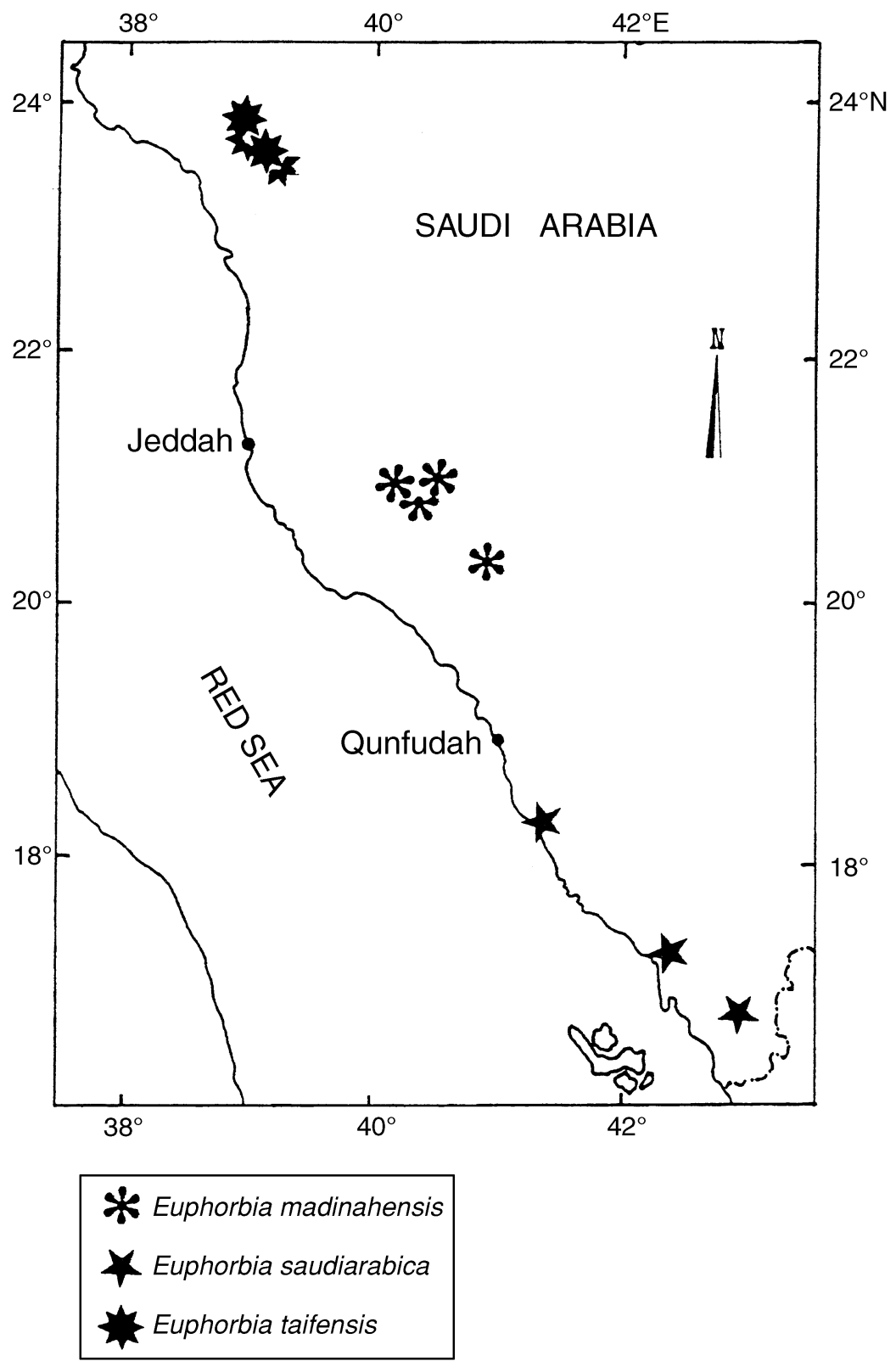

FIG. 5. Distribution of Euphorbia madinahensis, E. saudiarabica and E. taifensis.

erecti $20-40(-50) \mathrm{cm}$ in circumscriptio, 3-6(-7)-anguli, angulis acutis, spinis validis gemellis secus cristas striatas, scutis spinarum fere contiguis. Foliorum rudimenta, praecipue juvenilia, e rubro viridia, simplicia sessilia suborbiculata $5-5.5 \mathrm{~mm}$ longa, apice mucronato, margine fimbriato, mox decidua. Cyathia terna aggregrata, centrale masculo sessili primum florente, lateralibus bisexualibus 
pedicellatis pedicellis circa $4 \mathrm{~mm}$ longis, crescentibus masculum centralem occultantibus; cymae involucraque bracteata, bracteis sessilibus suborbicularibus vivide virentibus circa $4 \times 3 \mathrm{~mm}$. Involucrum poculiforme, 7-8 $\mathrm{mm}$ latum circa $5 \mathrm{~mm}$ profundum; glandulae cyathiorum flavae patentes transverse ellipticooblongae vel oblongo-triangulares $3.5 \times 1.8 \mathrm{~mm}$, lobis marginalibus margine fimbriatis. Flores masculi pedicello 5-7 mm longo, bracteolis 3.5-4 mm longis, in dimidio superiore dissectis. Flores feminei pedicellati, pedicello circa $1.4 \mathrm{~cm}$ longo, ovario laevi, ramis stylorum circa $3 \mathrm{~mm}$ longis, infra connatis per $2 \mathrm{~mm}$, ad apicem bifidis. Capsula lobis 3 rotundatus, $8 \times 18 \mathrm{~mm}$, in stipite $14-22 \mathrm{~mm}$ longo, matura vivide rubra. Semina subglobosa circa $3 \mathrm{~mm}$ longa grisea. - Type: Saudi Arabia: Taif city, Bani Salim District, about $15 \mathrm{~km}$ SE of Taif, $1750 \mathrm{~m}$ alt., 18 xii 1998, D. Al-Zahrani 198 (holo M; iso BM, CAI, E, K, KAAU, KSU, RIY).

A much branched, succulent, spiny tree, up to $10 \mathrm{~m}$ tall, glabrous in all parts; main stem 65-90 cm in circumference; branches bright green, upright, 20-40(-50) cm in circumference, 3-6(-7)-angled; angles acute, with pairs of stout spines up the fluted ridges; spine shields almost contiguous. Leaf rudiments reddish-green especially when young, simple, sessile, suborbicular, 5-5.5 mm long, apex mucronate, margin fimbriate, soon deciduous. Cyathia in groups of three; the central male, sessile, flowering first; the lateral bisexual, pedicellate, pedicel c. $4 \mathrm{~mm}$ long, obscuring the male cyathium as they develop; cymes and involucres bracteate; bracts sessile, suborbicular, bright green, c. $4 \times 3 \mathrm{~mm}$. Involucre cup-shaped, 7-8 $\mathrm{mm}$ across, c. $5 \mathrm{~mm}$ deep; cyathial glands yellow, patent, transversely elliptic-oblong to oblongtriangular, $3.5 \times 1.8 \mathrm{~mm}$; marginal lobes with fimbriate margin. Pedicel of male flowers 5-7 mm long; bracteoles 3.5-4 mm long, dissected in the upper half. Pedicel of female flower stout, c. $14 \mathrm{~mm}$ long; ovary smooth; style arms c. $3 \mathrm{~mm}$ long, connate for $2 \mathrm{~mm}$ below, bifid at apex. Capsule with 3 rounded lobes, $8 \times 18 \mathrm{~mm}$ on 14 $22 \mathrm{~mm}$ long stalk, ripening bright red. Seeds subglobose, c. $3 \mathrm{~mm}$ long, grey.

Distribution. Euphorbia taifensis is named after Taif city where the species is endemic (Fig. 5).

Habitat and flowering times. The plants are very localized, occurring on the stony and rocky slopes of wadis and near farms at elevations ranging between 1700 and $2100 \mathrm{~m}$. The new species is well established and occurs in large colonies with good regeneration. Flowering and fruiting from October to February.

Vernacular names. Amaq, Amaqah, Amaqat al-ghanam.

Conservation status. The new species has both an extent of occurrence of less than $20,000 \mathrm{~km}^{2}$ and an area of occupancy of less than $2000 \mathrm{~km}^{2}$. It is known to exist at no more than 10 locations and continuing decline has been observed. It is therefore to be considered as Vulnerable (VU) under criteria Blab (i,ii,iv,v) + 2ab (i,ii,iv,v) according to the IUCN Red List Categories and Criteria, version 3.0 and 3.1 (IUCN, 2001, 2003). 
TABLE 3. Comparison of morphological characters in Euphorbia taifensis and E. ammak

\begin{tabular}{lll}
\hline \hline Character & E. taifensis & E. ammak \\
\hline Habit & Up to $10 \mathrm{~m}$ tall & Up to $6 \mathrm{~m}$ tall \\
Leaf & & \\
- Colour & Reddish-green & Green \\
- Size & $5 \times 5.5 \mathrm{~mm}$ & $6 \times 10-20(30) \mathrm{mm}$ \\
- Apex & Mucronate & Acute \\
- Margin & Fimbriate & Entire \\
Capsule & & \\
- Size & $8 \times 18 \mathrm{~mm}$ & $7-10 \times 12(-14) \mathrm{mm}$ \\
- Shape & Triangular, rounded & Triangular, acute \\
- Pedicel & $14-22 \mathrm{~mm}$ & $9-11 \mathrm{~mm}$ \\
\hline \hline
\end{tabular}

This new species is similar in its growth form and involucral characters to Euphorbia ammak Schweinf. However, Euphorbia taifensis is easily distinguished through its leaf characters: reddish-green, 5-5.5 mm long, suborbicular, with mucronate apex and fimbriate margins. In addition our species is taller (attaining $10 \mathrm{~m}$ ). Moreover, the capsule lobes are rounded and the inflorescence size is quite different. A morphological comparison between Euphorbia taifensis and E. ammak is given in Table 3.

Specimens examined. SAudi Arabia. Thaqif, Sakharah village, 9 vii 1946, Vesy-FitzGerald 16560 (BM); Near Haritha, Wadi Wahht, SW of Taif, 2170 m alt., 21 xi 1986, Collenette 5928 (E, RIY); Taif, Bani Salim District, $15 \mathrm{~km} \mathrm{SE}$ of Taif, $1750 \mathrm{~m}$ alt., 18 xii 1998, D. Al-Zahrani 198 (BM, CAI, E, K, KAAU, KSU, M, RIY); Taif, Bani Salim District, $15 \mathrm{~km}$ SE of Taif, $1750 \mathrm{~m}$ alt., 25 xii 1998, D. Al-Zahrani 199 (KAAU); Jebal Amudh, by wadi Aoff wadi Wijj, $18 \mathrm{~km}$ from Taif, $2000 \mathrm{~m}$ alt., 9 iv 1978, Collenette 627 (K); Taif, wadi Sakarah, between Misan and Al-Baha, 28 xi 1992, Collenette 8433 [spirit sample no. 62829 (K)]; Wadi Sakarah, 4 iii 1993, Collenette 7940 [spirit sample no. 57329 (K)].

\section{ACKNOWLEDGEMENTS}

We are greatly indebted to the directors and members of staff of the herbaria at the Royal Botanic Gardens, Kew, Royal Botanic Garden Edinburgh, and British Museum (Natural History) for the facilities provided, valuable discussions and useful comments. Thanks are also due to the authorities of the Faculty of Science, King Abdulaziz University in Jeddah, Faculty of Science, King Saud University in Riyadh, and the National Herbarium in Riyadh for offering facilities to conduct this work. We would also like to thank two anonymous referees for their valuable comments and for useful discussions.

\section{REFERENCES}

Collenette, S. (1985). An Illustrated Guide to the Flowers of Saudi Arabia. London:

Scorpion Publishing.

Collenette, S. (1987). Spiny Euphorbias in Arabia. Euphorbia J. 4: 102-122. 
Collenette, S. (1999). Wildflowers of Saudi Arabia. NCWCD, Kingdom of Saudi Arabia. IUCN (2001). IUCN Red List Categories and Criteria: Version 3.1. IUCN Species Survival Commission. Gland, Switzerland and Cambridge, UK: IUCN.

IUCN (2003). Guidelines for Using the IUCN Red List Categories and Criteria: Version 3.0. IUCN Species Survival Commission. Gland, Switzerland and Cambridge, UK: IUCN.

Received 2 September 2006; accepted for publication 12 February 2007 